\title{
中性子による重水濃度の測定
}

\section{Analysis of Heavy Water Concentrations by Fast Neutrons}

\author{
戸 根 弘 人* \\ HiROHITO TONE
}

(1975年 3 月10日受理)

\begin{abstract}
Studies on the analysis of heavy water concentrations by fast neutrons were carried out. When heavy water is irradiated by fast neutrons, there is a correlation between the heavy water concentration and the amount of thermal neutrons in heavy water.

Ten $\mathrm{mCi}$ of ${ }^{241} \mathrm{Am}-\mathrm{Be}$ was used as a fast neutron source, and the heavy water volumes used in the experiments were 1, 2 and 5 liters. It is found from the experimental results that there are following relationships between the heavy water concentration $(C)$ and counting rate $(N)$ of thermal neutrons in heavy water: $N=K_{1}$ exp $(-P C)$ at the concen. tration of less than 80 mole $\%$, and $N=-K_{2} C+q$ at the concentration of greater than 80 mole $\%$.

The sensitivity of this heavy water analysis, which is defined as the minimum change of the heavy water concentration to be detected, is 0.5 mole $\%$ on the average. Boron and uranium, which are neutron absorbers in heavy water, decreased accuracy of the analysis, and the effect of the void was also determined.
\end{abstract}

\section{1.まえがき}

重水はすぐれた核特性を有するために，原子力産業 の分野において多量に使用されている重要な物質の一 つである。特に, 重水 $\left(\mathrm{D}_{2} \mathrm{O}\right)$ は熱中性子の吸収断面 積が軽水 $\left(\mathrm{H}_{2} \mathrm{O}\right)$ に比べて小さいため, 重水を中性子 の減速材として使用する重水炉は核燃料に天然ウラン を使用できるという特長をもっている。重水炉では, 重水が高価であること, 重水濃度が原子炉の特性に影 響を与えること, などの理由で重水濃度のモニタリン グが重要視されている。

精度の高い重水濃度の測定は質量分析計によって行 なわれ，その分析法は確立されている。しかし，質量 分析法は熟練と多くの時間を必要とするため, 重水濃 度の管理分析には不適当である。このため, 重水炉で は精度は悪いが分析操作の簡単な赤外吸収法が一般に 使用されている。しかしながら，赤外吸収法によって 測定できる重水の濃度範囲は非常にせまく, 約 $98 \mathrm{~mol}$ \%から $99.7 \mathrm{~mol} \%$ である。重水濃度が $98 \mathrm{~mol} \%$ 以下
になると, $\mathrm{H}_{2} \mathrm{O}$ の赤外吸収が非常に強く現れて $\mathrm{D}_{2} \mathrm{O} の$ 赤外吸収を妨害するため, $98 \mathrm{~mol} \%$ 以下の重水濃度の 測定は不可能である。このように，赤外吸収法は高濃 度重水の測定に適しているが，その測定できる濃度範 囲がせまいため, 重水濃度の管理分析には不十分であ った。このため, この方法に代る新しい重水濃度の測 定方法を検討する必要が生じた。

良く知られているように, 重水素 (D) と軽水素

（H）では高速中性子に対する減速効果が非常に異な り，さらに熱中性子の吸収断面積も異なっている。著 者らは,このように高速中性子と重水素および軽水素 との物理的相互作用の差を利用した重水濃度の分析法 に注目し，検討を行なってきた。その結果，このよう な原理にもとづく重水濃度分析の可能性が得られたの で，その結果を報告する。

\section{2. 実験}

\section{1 実験装四}

実験装置をFig. 1 に示す。実験装置は測定用の重水

*日本原子力研究所大洗研究所 (茨城県東茨城郡大洗町)

Japan Atomc Energy Research Institute, Oarai Research Establishment (Ōarai-machi, Ibaraki-ken, 311-13 Japan) 


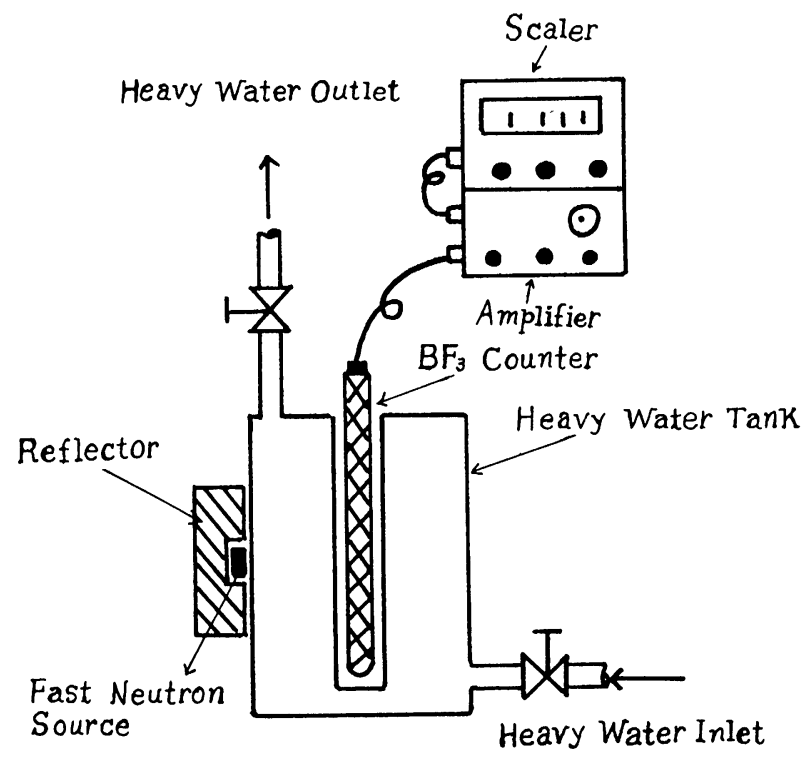

Fig. 1. Schematic diagram of the experimental equipment.

タンク, 高速中性子源, 高速中性子の反射体, $\mathrm{BF}_{3}$ 計 数管, 増幅器, スケーラー, レートメーターおよび記 録計よりなる。高速中性子源として $10 \mathrm{mCi}$ の $^{241} \mathrm{Am}-\mathrm{Be}$ 中性子源を使用した。この中性子源の強度は $2.7 \times 10^{\circ}$ $\mathrm{n} / \mathrm{sec}$ で, 放出される中性子の平均エネルギは $5.48 \mathrm{MeV}$ である。 ${ }^{241} \mathrm{Am} の$ 半隇期は 461 年であるから, 中性子源 の強度は実験中は変らないと考えてよい。この高速中 性子源を鉛の反射体で覆って円籄状のステンレス製の 重水タンクの側面にとりつけた。反射体は重水タンク と反対方向に放出された高速中性子を重水タンク内に 反射させる働きをし, $15 \mathrm{~cm} \times 10 \mathrm{~cm} \times 5 \mathrm{~cm}$ の直方体であ る。測定用重水タンクの中心には熱中性子測定用とし
て $\mathrm{BF}_{3}$ 計数管を置いた。重水濃度測定に与える重水体 䅡の影響をしらべるため, 容積が $1 l, 2 l, 5 l$ の 3 種類の重水タンクを用いた。次に，重水中に含まれる 気体によってボイドが生じると, 重水中の熱中性子量 が変化し, 重水濃度測定に影響を与える。このため, ボイドの影響を測定する必要があった。

Fig. 2 は重水中のボイドによる影響を測定するため の装置である。Fig. 2 の装置はFig. 1 の実験装置に ボイド発生装置をとりつけたものである。窒素および 重水の各流路に設けられた流量計および制御升によっ て重水および窒素の流量を制御し，任意のボイド百分 率を得ることができる。

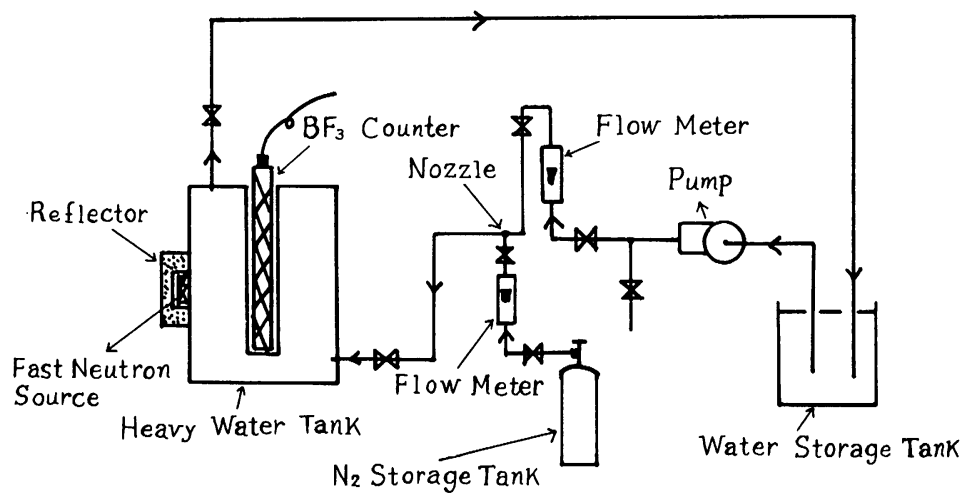

Fig. 2. Schematic diagram of the apparatus to measure the void effect in heavy water. 


\section{2 重 水}

実験に使用した重水は濃度 $99.7 \mathrm{~mol} \%$ で，電気伝導 度 $10 \times 10^{-\circ} \Omega i^{-1} \cdot \mathrm{cm}^{-1}$ の純水である。99.7 $\mathrm{mol} \%$ の重水

濃度は日立製RM-D3 型重水用質量分析計によって 検 定した。この $99.7 \mathrm{~mol} \%$ 重水を蒸溜水で希釈し, 低 濃度の重水試料を調製した。蒸溜水に含まれる重水の 存在率は $0.015 \mathrm{~mol} \%$ である。

\section{3 実検方法}

Fig. 1 の重水タンク内に濃度既知の重水を満たし, ${ }^{201} \mathrm{Am}-\mathrm{Be}$ 中性子源から放射される5.48MeVの高速中 性子を照射した。重水中で減速して生じた熱中性子を 重水タンク中心部にもうけた $\mathrm{BF}_{3}$ 計数管によって測定 し, 重水濃度と熱中性子計数值の関係を求めた。重水 体積の影響をしらべるため，重水タンクの体積が $1 l$, $2 l$ およ゙ $5 l$ の各場合について同様の測定を行なっ た。次に，Fig. 2 の装置を用いて重水濃度測定に与え るボイドの影響を測定した。ポンプによって循環する 重水に窒素ガスをノズルから注入してボイドを発生さ せ，上記と同様の方法でボイド効果を測定した。また， 重水中に熱中性子吸収断面積の大きなホウ素やウラン が含まれている場合の重水濃度測定に与える効果を Fig. 1 の装置を用いて同様に測定した。

\section{3. 測 定 結 果}

\section{1 重水潧度}

測定結果をFig. 3 に示す。Fig. 3 は $1 l, 2 l$ よび

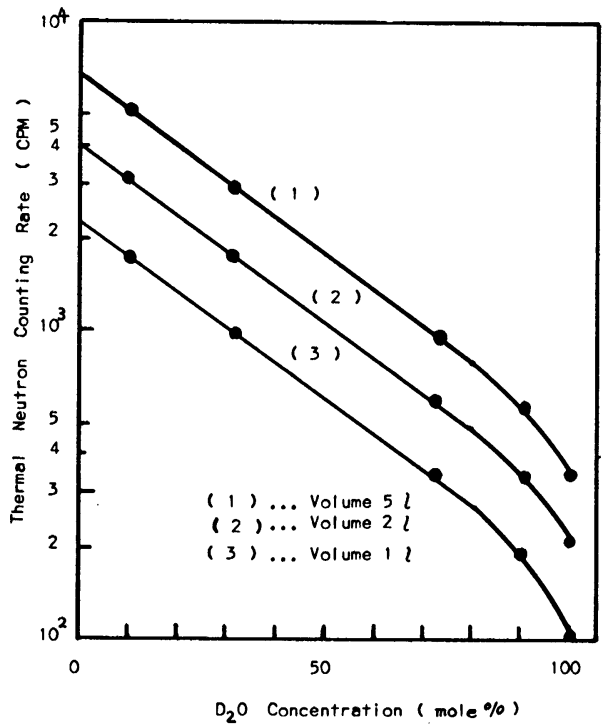

Fig. 3. Relationship between the heavy water concentration and counting rate of thermal neutrons at $25^{\circ} \mathrm{C}$.
$5 l$ 重水体積における測定結果である。

Fig. 3 において, 重水濃度が軽水から $80 \mathrm{~mol} \%$ の範 囲では, 得られた片対数プロットによるグラフは直線 となる。しかし, 重水濃度が $80 \mathrm{~mol} \%$ 以上ではグラフ は直線からはずれて曲線となっている。高濃度の重水 と熱中性子計数値の関係を詳細にしらべるため, 等目 盛にプットするとFig. 4 が得られる。Fig. 4 のグラフ を見ると, 濃度 $80 \mathrm{~mol} \%$ 以上で重水濃度対計数值は直 線関係を満足している。なほ, 測定時の重水温度は約

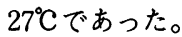

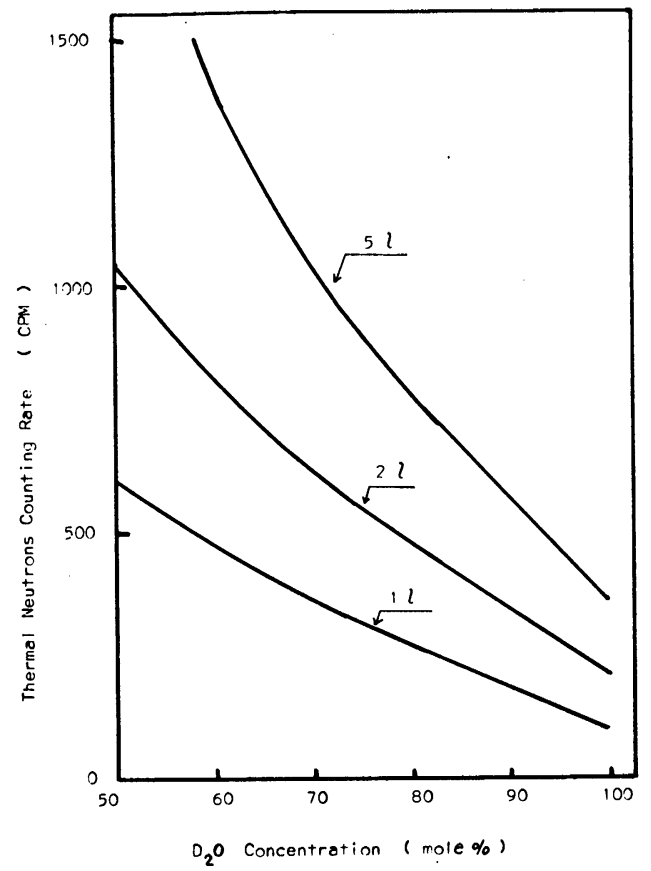

Fig. 4. Heavy water concentration vs. neutron counting rate for the high concentration region.

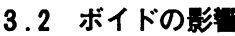

測定する重水中に気泡などのボイドが含まれると， このボイドによって濃度測定は影響をうける。すなわ ち, 重水中にボイドが存在すると正味の重水体積が減 少する。重水体積が減少すると中性子の洩れが増加し， この結果熱中性子計数值が減少する。

Fig. 2 の実験装置によって，ボイドの容積百分率に 対する熱中性子計数值の変化を測定した。重水容䅡 2 lのボイド効果の測定結果を Fig. 5 に示す。Fig. 5 の曲線（1）は軽水, 曲線（2）は重水濃度 $90.2 \mathrm{~mol}$ \%の測定結果である。予想された通り，ボイドの量が 増加すると熱中性子計数值の減少が見られた。 


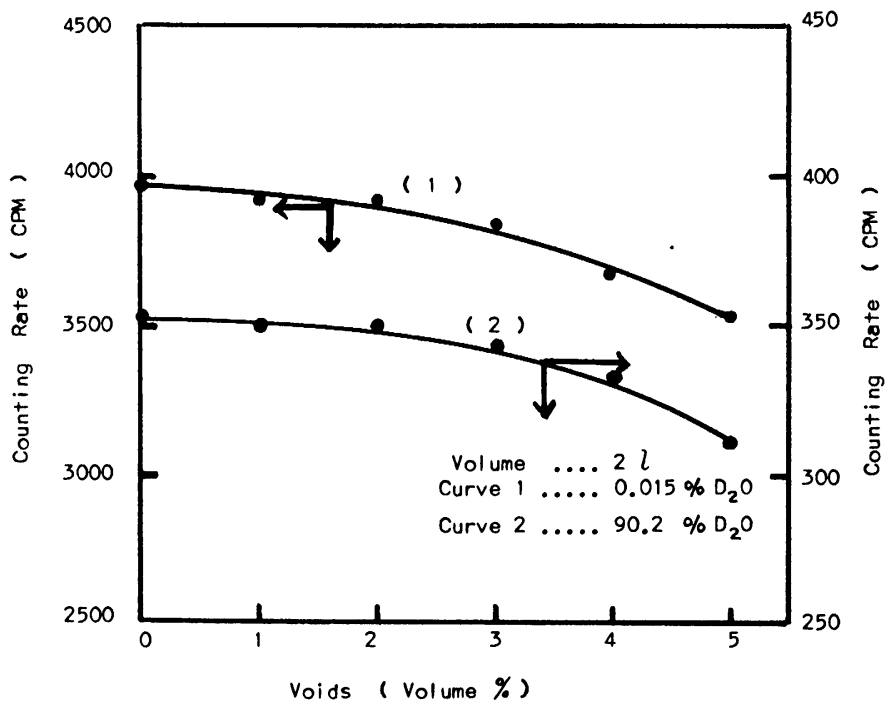

Fig. 5. Effect of voids in heavy water at $25^{\circ} \mathrm{C}$.

\section{3 不純物の影輁}

重水中に中性子吸収断面積の大きな不純物が含まれ ていると, 中性子がこの不純物に吸収されるため, 重 水濃度の測定値は不純物の影響をうける。

重水中にウランまたはホウ素のような中性子吸収断 面積の大きな物質が含まれているとき，これらの物質 が重水濃度測定に与える影響を軽水および $90.2 \mathrm{~mol} \%$ の重水について測定した。ウラン溶液は硝酸ウラニル $\left(\mathrm{UO}_{2}\left(\mathrm{NO}_{3}\right)_{2} \cdot 6 \mathrm{H}_{2} \mathrm{O}\right)$ を重水に溶解して調整した。
使用したウランは天然ウランで熱中性子吸収断面積は 7.68 バーンである。ホウ素溶液はホウ酸 $\left(\mathrm{H}_{3} \mathrm{BO}_{3}\right)$ を 重水に溶解して調整した。ホウ素の熱中性子吸収断面 䅡は755バーンである。

測定結果をFig. 6, Fig. 7 に示した。Fig. 6 はウラ ン濃度に対する熱中性子計数值の測定結果であり,

Fig. 7 はボロンを含む重水についての測定結果である。 動力炉では最大 $1500 \mathrm{ppm}$ 程度のホウ素を原子炉の化学 制御材として冷却水に添加する場合がある。このため,

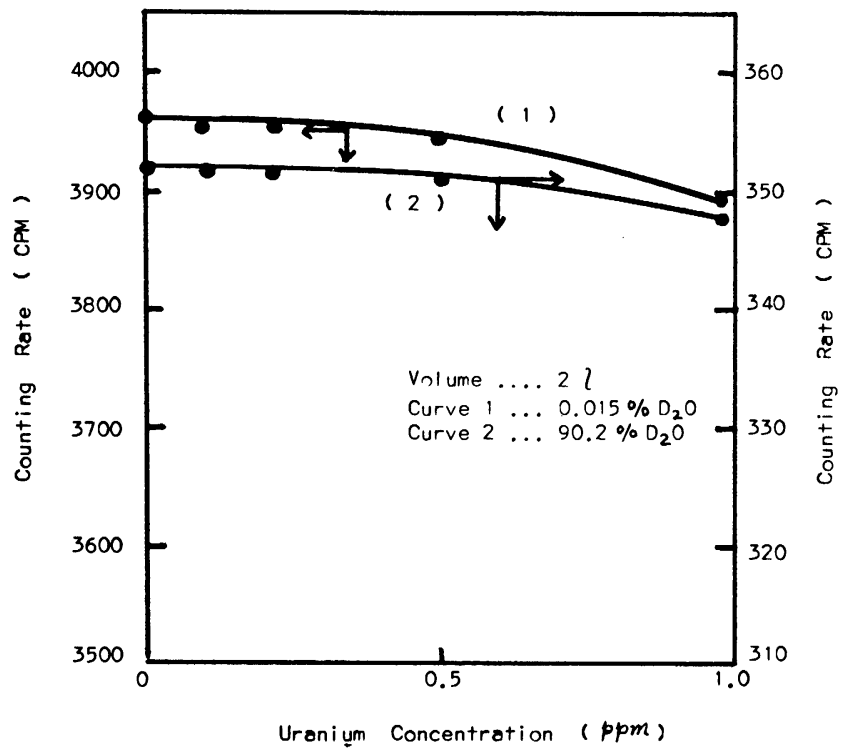

Fig. 6. Influence of uranium on the measurement of the heavy water concentration. 
中性·ケによる重水满恔の測定

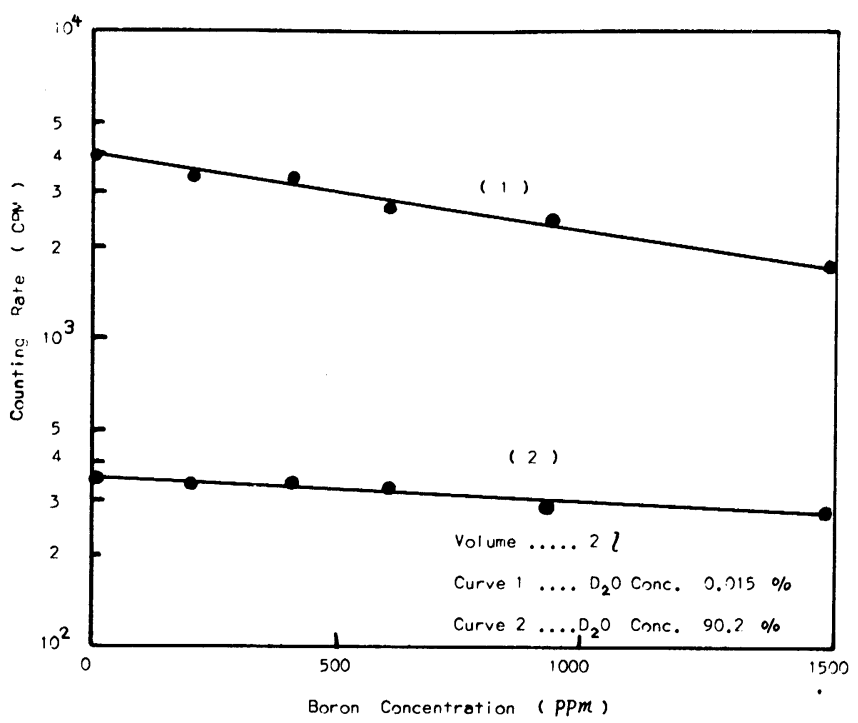

Fig. 7. Influence of boron on the measurement of the heavy water concentration.

最大1500ppmのホウ素が重水に添加されることを想定

して，ホウ素の影響を測定した。

\section{4. 考察}

\section{1 重水溍度と計数值}

Fig. 3 およびFig. 4 のグラフから，熱中性子計数值 を $N$, 重水濃度を $C$ で表わすと, 重水濃度が $80 \mathrm{~mol} \%$ 以下のとき計数値 $N$ は(1)式で表わされる。

$$
N=K_{1} \exp (-P C)
$$

また, 重水濃度が $80 \mathrm{~mol} \%$ 以上では, 計数值 $N$ は (2) 式で表わされる。

$$
N=-K_{2} C+q
$$

ただし， $K_{1}, K_{2}, P$ おび $q$ は定数である。

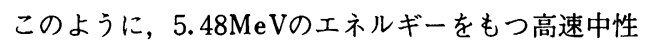
子が小容量の重水中に入射したとき, 中性子は重水濃 度によって2つの異なった挙動を示すことがわかった。 重水中の中性子の動きを詳細に解析すると, 次の $6 \supset$ の過程に分類できる。すなわち, (1)高速中性子の発生, (2)重水中での減速, (3)減速過程での系外えの洩れ，(4) 熱中性子の拡散, (5)拡散過程での系外えの洩れ, (6)軽 水素および重水素による熱中性子の吸収，などである。 上にのべた中性子の $6 \supset$ 過程が熱中性子計数值とど のような関係にあるかを調べるため, 減速および拡散 過程を数量的に表わしている減速距離および拡散距離 を用いて重水濃度と熱中性子計数值との関係を検討し
た。

ここで, 減速距離（一般に $\sqrt{\tau}$ で表わされる）は高 速中性子が熱中性子になるまでに走行する距離に相当 する量である。また, 拡散距離 $(L)$ は高速中性子が 熱中性子となった点からそれが吸収されるまでに走行

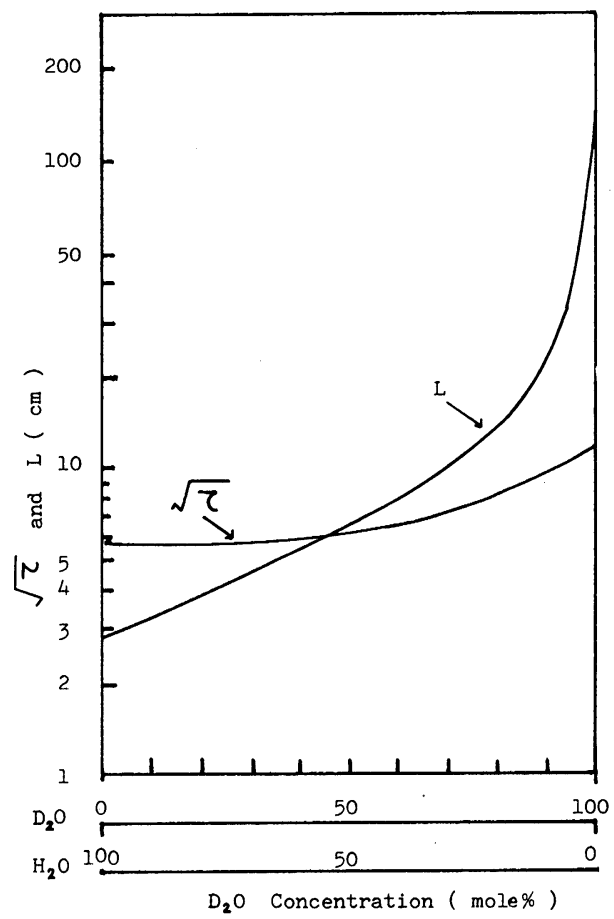

Fig. 8. Relationship among heavy water concentration, slowing down length, and diffusion length. 
した距離に関係する是である。減速距離および拡散距

離は共に長さの単位 $(\mathrm{cm})$ を持っている。

重水溇度と $(\sqrt{\tau})$ および $(L)$ との関係をプロッ トするとFig. 8 が得られる。

原子炉理論によれば，均一な媒質内において高速中 性子が減速過程の途中で媒質外へ洩れて出ない確率は (3)式で表わされる。

(減速中に洩れて出ない確率) $=\mathrm{e}^{-B^{2} \tau}$

また，熱中性子が媒質に吸収されるまでに系外へ洩 れて出ない確率は次式で表わされる。

(熱中性子の洩れて出ない確率 $)=\frac{1}{1+L^{2} B^{2}}$

ここで，Bは媒質の形状などによって決まる定数であ る。重水濃度が約 $90 \mathrm{~mol} \%$ 以上ではFig. 8 より $L^{2} \gg \tau$ が成立し, (4)式の熱中性子の洩れて出ない確率が隇少 するので, 熱中性子の拡散過程が計数值の支配因子と なる。重水浱度が $40 \mathrm{~mol} \%$ 以下では $\tau>L^{2}$ となるので, 低浱度の重水中では高速中性子の減速過程が計数值に 対して支配的になる。

\section{2 水体积の効果}

重水の体積が增加すると, 重水タンクの外に洩れ出 る中性子数が減少するので, 熱中性子計数值が増加す る。Fig. 3 の測定結果より重水体積と熱中性子計数值 の関係を求めてFig. 9 に示した。曲線(1)は軽水の測定 值, 曲線(2)は99. $7 \mathrm{~mol} \%$ 重水の測定值である。1 l から

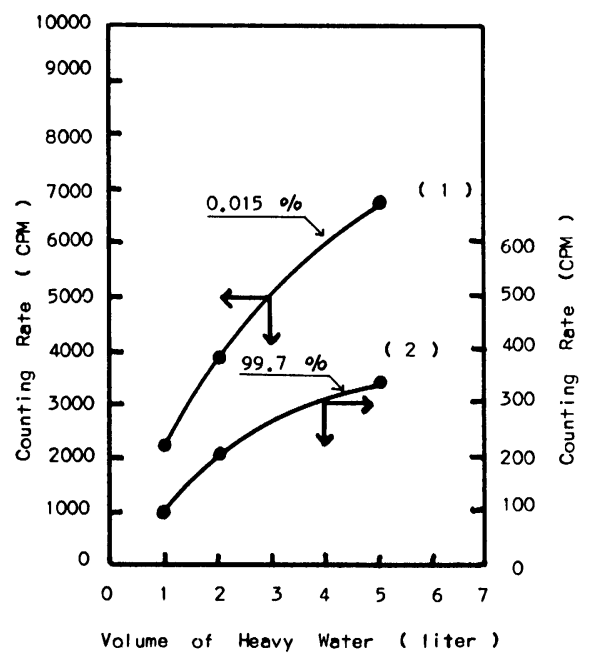

Fig. 9. Relationship between the counting rate of thermal neutrons and the heavy water volume.
数しの範囲では, 熱中性子と重水体積の関係はかなり 良い近似で次式により表わすことができる。

$$
N=Q V^{1 / x}
$$

ここで, $N$ は熱中性子計数値 $(\mathrm{cpm}), V$ は重水体積 $(l), x$ は重水浱度で決まる定数である。Qは $V=1 に$ おける熱中性子計数值に等しい。 $x$ の值は重水濃度に よって異なるが，その值は1.3から1.4であった。

\section{3 ボイドおよひ不純物}

測定する重水中にボイドが存在すると, 重水タンク 内の正味の重水体積が減少するので, 熱中性子計数值 が低下する。したがって，ボイドの影響は基本的には Fig. 9 に示した体積変化と同一である。いま，重水中 のボイド率をととすると正味の重水体積は $V(1-\varepsilon)$ である。したがって，(5)式より熱中性子計数值 $(N)$ は

$$
N=Q[V(1-\varepsilon)]^{1 / x}
$$

で表わされる。このとき（6)式のVは重水タンク容䅡 である。Fig. 5 に示した測定結果より(6)式の $x$ を求め ると, 軽水の $x$ は $1.3,90.2 \mathrm{~mol} \%$ 重水の $x$ は1.2である。 この值を(5)式の重水体積効果で求めた $x$ 值と此較する と，かなり良く一致している。したがって，ボイド奻 果は重水体積変化と同じ効果であることがこれによっ て確められた。次にホウ秦の影響であるが, Fig.7の 測定結果からホウ素浱度と計数值の間には近似的に指 数関数的な関係が存在する。Fig. 7 の曲線(1)と曲線(2) の勾配が異なっているが，このことは，重水浱度によ ってホウ素の影響が異なることを示している。

次に，ウランが重水に0.98ppm含まれるとき，熱中 性子計数值の減少率は軽水で $1.8 \%, 90.2 \mathrm{~mol} \%$ 重 水 で1.1\%であった。原子炉の場合，重水にウランが混 入するケースは $2 つ$ つ。一つは燃料被覆管表面に付 着した污染ウランの混入であり，他の一つは核燃料の 破損である。重水港度測定で問題となるのは原子炉定 常運転時の污染ウランの影響である。しかし，重水に 混入する污染ウラン量はトレースレベルであるため, 一般には重水浱度測定に与えるウランの影響は無視し うると考えてよい。

\section{4 検出感度}

$\mathrm{BF}$,計数管およびスケーラーを組み合わせた熱中性 子計数装置の検出しうる限界計数率は統計的に次式で 求められる。 


$$
n=\frac{k}{2}\left[\frac{k}{t_{\mathrm{s}}}+\sqrt{\left.\left(\frac{k}{t_{\mathrm{s}}}\right)^{2}+4 n_{\mathrm{b}}\left(\frac{1}{t_{\mathrm{s}}}+\frac{1}{t_{\mathrm{b}}}\right)\right]}\right.
$$

ここで, $n$ は限界計数率 $(\mathrm{cpm}), n_{\mathrm{b}}$ はバックグランド 計数率 $(\mathrm{cpm}), t_{\mathrm{s}}$ は熱中性子の計数時間 $(\mathrm{min}), t_{\mathrm{b}}$ はバックグランド計数時間 $(\mathrm{min}), k$ は統計的に定ま る定数で, 通常は 3 を用いる。

本実験では，熱中性子計数誤差を $2 \%$ 以下にするた めに，測定時間を計数率に応じて選択した。また，各 測定のバックグランド計数率は平均 $11 \mathrm{cpm}$ で, その計 数時間は15分であった。これらの測定条件にもとづい て, (7)式より検出しうる限界計数率を求め, この限界 計数率とFig. 3 に示した測定結果から重水の検出感度 を求めた。重水濃度および重水体積によって, 本実験 の重水検出感度は異なる。得られた検出感度は $0.3 \mathrm{~mol}$ '\%から $0.7 \mathrm{~mol} \%$ の間に分布し，この平均值は $0.5 \mathrm{~mol}$ \%であった。

\section{5. をとめ}

中性子による重水の濃度測定の実験を行ない, 重水 濃度 $80 \mathrm{~mol} \%$ 以上では重水濃度と熱中性子計数値の間 に直線関係が成立し，重水濃度 $80 \mathrm{~mol} \%$ 以下では熱中 性子計数值は重水浱度の指数関数で表わされることを 明かにした。本測定法を他の方法と比較すると, 検出 感度は質量分析法が最も良く，次が赤外吸収法である。 波長 $3 \mu \mathrm{m}$ から $4 \mu \mathrm{m}$ の赤外吸収を利用する赤外吸収法 の検出感度は $98 \mathrm{~mol} \%$ から $99.7 \mathrm{~mol} \%$ 重水濃度で 0.1 mol\%以下である。

しかし，赤外吸収法で測定できる重水濃度は98mol \%から $99.7 \mathrm{~mol} \%$ で，その測定範囲が非常にせまい。 重水濃度が $98 \mathrm{~mol} \%$ 以下になると. $\mathrm{H}_{2} \mathrm{O}$ 分子による波 長 $3 \mu \mathrm{m}$ の赤外吸収スペクトルが非常に増大するので, 波長 $4 \mu \mathrm{m}$ の $\mathrm{D}_{2} \mathrm{O}$ 分子の赤外吸収スペクトルは測定 不 可能となる。
これに対して，中性子による重水浱度測定法は検出 感度の点で赤外吸収法に劣るが, 軽水から高搌度重水 まで総ての濃度範囲を測定することができる。このた め, 重水炉の一次熱交換器に腐食孔またはクラックな どが生じ, 二次冷却材の軽水が混入するような事故が 生じたときの重水濃度の低下を監視する装置として十 分使用することができる。

さらに，本実験では強度一定の中性子源と容量の異 なる 3 種類の重水タンクを組み合わせて測定を行なっ た。

しかし, 重水の検出感度および測定精度は中性子源 の強度および重水体積によって変るので, 今後さらに どのような組合せが重水濃度測定に最も適しているか を検討する必要がある。

\section{文献}

1) P. Cohen and H.W. Graves, Nucleonics, 22, 75 (19 (1964).

2 ) J. A. Thin, Nucleonics, 16, 82 (1958).

3 ) C. R. Breden and U. S. Brown, ANL-5244 (1963).

4) Argonne National Laboratory, ANL-5800, 129 (1963).

5 ) 南蜸太郎 - 佐藤信之, JAERI-memo-2703 (1967).

6) J. Gaunt, Spectrochemica Acta, 8, 57 (1956).

7) W.H. Stevens and W. Thurston, CRC-568 (1956).

8 ) J. Gaunt, The Analyst, 79, 580 (1954).

9 ) 谷口 犦, 分光研究, 11, 217 (1963). 